Praveeni S.M.N., Wickramasinghe C.N., KJM, 2021, 10 (Special Issue)

\title{
Impact of Smartphone Addiction on Academic Performance of Undergraduates in Sri Lanka: Mediating effect of Technology Driven Multitasking
}

\author{
Praveeni S.M.N. ${ }^{1}$ and Wickramasinghe C.N. ${ }^{2}$ \\ ${ }^{1}$ Department of Business Management, Faculty of Business Studies and Finance, Wayamba \\ University of Sri Lanka \\ ${ }^{2}$ Department of Commerce and Financial Management, Faculty of Commerce and \\ Management Studies, University of Kelaniya, Sri Lanka \\ 1 praveeni@wyb.ac.lk, ${ }^{2}$ nalakacw@kln.ac.lk
}

\begin{abstract}
This study aimed to examine university undergraduate's level of Smartphone Addiction (SA) and to investigate the impact of SA on their Academic Performance (AP) with the mediating effect of Technology-Driven Multitasking behaviour (TDMT). The study employed a crosssectional survey design, with data gathered from 315 university students. The scope is limited to management undergraduates in Sri Lanka. Descriptive and inferential analysis was used while regression analysis was applied to test hypotheses. Further, the Sobel test is used to test the mediate effect in the relationship between Independent Variable (IV) and Dependent Variable (DV. The study put forth that university students were highly addicted to the use of smartphones. SA negatively impacts AP while TDMT also negatively impacts DV. Further, TDMT mediates the relationship between IV and DV. This study suggests that the students should reduce the intense use of smartphones for smoothly doing their academic activities.
\end{abstract}

Keywords: AP, SA, TDMT, Undergraduates

Copyright: () 2021 Praveeni S.M.N. and Wickramasinghe C.N. This is an open access article distributed under the Creative Commons Attribution License, which permits unrestricted use, distribution, and reproduction in any medium, provided the original work is properly cited.

Correspondence: praveeni@wyb.ac.lk

ORCID of authors: $\quad$ Praveeni, S.M.N. : https://orcid.org/0000-0003-2438-4902

DOI: http://doi.org/10.4038/kjm.v10i0.7681 


\section{Introduction}

Over the last decade, smartphones are fully penetrating into human lives. People moving their fingers on the smartphones' screens in homes, offices, parks, markets, bus stops, and even in classrooms. The smartphone has become one of the most pervasive technological devices in humans' day today lives (Alfawareh and Jusoh 2014; Emanuel et al. 2015; Hossain and Ahmed 2016). Interestingly, the use of smartphones has momentously blown up in the last few years, driven mainly by the ubiquitous nature of this technology, lower costs, access and affinity displayed by this demographic group, to these devices (Prensky, 2001). As per the statistics shared by Deloitte in the Global Mobile Consumer Survey, the US edition, mobile phone penetration in the US alone is $85 \%$ among the baby boomers and about $90 \%$ among the millennials. The proliferated use of smartphones poses new challenges for higher education institutes along with the detrimental effects these devices have on the overall academic performance of university students.

University students use smartphones for playing games, music, and videos, surfing on the Internet, accessing their bank accounts, checking news and weather, connecting on social media and using several other applications and feature their phones provide and even while they are in the classroom (Emanuel et al. 2015). Generally, smartphones addiction can be viewed as a mental state where a person is so much attracted to the multitasking functions and applications of the smartphones and where he/she uses it as his/her daily routine activity.

The Social Construction of Technology Theory approach identified that psychological motives might stimulate the technology adaptation rather than the availability and the affordability of those technologies (Bijeker et al. 1987). Inline, with that researcher considered SA as a psychology motive that enables technologydriven multitasking ability of the undergraduates.

A Study (Fox, Rosen, \& Crawford, 2009) found that most college students tend to multitask most of their activities with the use of smartphones and engage with technological activities than reading in leisure time. Compared with the past, students use technology and tend to multitask, very often during learning activities, and it has become a commonplace in the university classroom (Calderwood, Ackerman \& Conklin 2014). Furthermore, smartphone use may interfere with studyrelated activities. The proximity of the mobile device can be a tempting distraction, leading to multitasking or task-switching. A growing body of literature (Junco, 2012; Junco \& Cotten, 2012; Levine, Waite, \& Bowman, 2012) has shown this behaviour's negative implications with respect to educational performance.

The threaded cognition theory by Salvucci and Taatgen (2008) argued that two different conditions cause active goals to be displaced in favour of others: external interruptions and internal voluntary decisions to stop an ongoing task to attend to another and emphasized memory as a central process in task suspension and resumption; thus, interrupting tasks with more significant memory usage should, in general, cause more disruption will lead to a decrease in overall performance on the task. Another study found evidence to prove that undergraduate business students sacrifice certain academic works and study time because of "technological distractions" such as Facebook, YouTube, Viber and other similar electronic information and communication technologies. These factors are profoundly impacting student focus, attention, distraction and consequently, AP (Fox, Rosen, \& Crawford, 2009).

Researchers, around the globe, studied students' perspectives about SA and found 
that smartphones entertain students and help them to escape from academic pressure. Students usually use smartphones for selfexpression and to maintain their social relations (Albarashdi et al., 2016). On the other side, it has also been found that in some cases, students use smartphone apps for their academic work (Kamran, 2010).

However, the excessive usage of a smartphone causes adverse effects on users who gradually become addicted to it. It has been observed that SA is more severe than the addiction to mobile phones, computers, and even the internet. Several studies have been conducted to measure the impact of SA and AP among university students. Alosaimi et al. (2016) and Aljomaa et al. (2016) studies conclude that SA creates negative impacts on students' AP. These contradictory findings may not give a clearcut answer.

Apart from that, most of the scholars investigated how SA impacts students' participation in their AP. Specifically, less attention took place regarding how SA impacts AP through TDMT. Based on the identified research gaps and the problem statement, a need is felt to carefully evaluate the manner, the current survey study attempted to inspect university students' SA direct and indirect impact on AP with the mediating effect of TDMT.

\section{Literature Review}

The term addiction has been mostly associated with drugs, alcohol, gambling etc. Technology addiction has been recognized since the mid-1990s as a new kind of social problem as the media started paying increasing attention to the idea of computer or internet addiction (Shaw \& Black, 2008). Accessed by computer, the Internet provides users with the opportunity to escape from one state of consciousness and visit different worlds of information with all the euphoric mind-bending properties associated with new adventures and problem-solving (Shaffer, 1996). With the onset of mobile phones, a new kind of addiction was found to be emerging.

Nowadays youth's lives revolve around mobile phones. Kibona and Mgaya (2015) researched to explore whether SA is creating any impact on students' AP. Researchers, James and Drenn (2005) have reported that university students spend about $1.5-5 \mathrm{~h}$ on their smartphones per day. A study on students in Pretoria suggests that mobile phone usage is dependency forming, compulsive and habitual and the researcher suggest that it may be the biggest non-drug addiction the 21 st century may be facing (Shambare, Rugimbana, \& Zhowa, 2012). In another research Roberts, Yaya, and Manolis (2014) suggest that addiction to one's cell phone is ultimately an attempt to escape another, more significant problem, such as boredom, low self-esteem, relationship trouble, etc.

The excessive use of smartphones and the psychological symptoms associated with them lead to SA (Bianchi \& Phillips, 2005). A study on Ruaha Catholic University students has revealed that impact of Smartphone on the AP of higher learning students, bring negative results or adverse effects on student's performance academically. When students were asked about the distractions they get when they are in class, and someone texted him/her, the majority accepted that they are distracted from the lectures and start on concentrating on replying to the messages send to them which eventually causes poor AP at the end of the semester (Kibona \& Mgaya, 2015). Aljomaa, Qudah, Albursan, Bakhiet, and Abduljabbar (2016) state that Smartphone addicts tend to neglect work and study, isolate themselves from friends and family and remain attached to the Smartphone. Smartphone addicts are positively related to psychological traits including locus of control, social interaction anxiety, materialism and the need for touch. 
In a number of other studies, smartphone and internet addiction were found to have negative effects on academic success as well (Erdem, et al., 2016; Lićwinko, Krajewska, Kulak \& Lukaszuk, 2011). Students who have excessive smartphone and internet use may have a harder time paying attention to course hours, participating in the active learning process in class, and participating in the school activities expected of them.

Hence, the researcher aimed to examine the extent of students' knowledge of SA by testing the following hypothesis,

H1: There is a significant impact of SA on the AP of university undergraduates.

H2: There is a significant impact of SA on TDMT of university undergraduates.

H3: There is a significant impact of TDMT on AP of university undergraduates.

H4:TDMT mediates the relationship between $S A$ and $A P$ of university undergraduates.

Based on the hypotheses formulated for this study, a conceptual model to be tested was developed. This is shown in Figure. I (Appendix A).

Measurement of Smartphone Addiction was measured through SAS-SV validated scale which was originally established in South Korea, but published in English (Kwon, Kim, et al., 2013). This scale is a shortened version of the original 40 items scale. It is a ten-item questionnaire used to assess levels of smartphone addiction. Participants were asked to rate on a dimensional scale how much each statement relates to them, (1 "strongly disagree" to 6 "strongly agree").

The frequency of multitasking during class was evaluated using the question "How often do you do the following activities during class?', with prompts for Facebook,
IM, email, talking on the phone, texting, and searching for information online that is not related to the class. The possible choices for multitasking frequencies will be worded: "Very Frequently (close to $100 \%$ of the time)"; "Somewhat Frequently (75\%)"; "Sometimes (50\%)"; " Rarely (25\%)"; and "Never" (Perera,2017; Junco and Cotton,2012).

The outcome of the study was the Academic Performance of the university undergraduates which was measured through academic performance proficiency scale (students' ability to perform academic tasks and solve problems) which is a fouritem scale, used in the study by $\mathrm{Yu}$ et al. (2010), who adapted it from Chao et al. (1994).

\section{Methodology}

The study applied the quantitative design utilizing the questionnaire for data collection. The questionnaire comprised four sections namely; the Independent variable section, the mediate variable section, the dependent variable and the generic information section. Gender, year of birth, university name, level of study and type of technology devices used formed the generic information. In addition, the IVs was SA and TDMT was the mediate variable while the dependent variable was AP.

\section{Sample Size and Sampling Technique}

The study targeted a population of 5196 levels three management faculty undergraduates in state universities in Sri Lanka. These respondents were born after 1995 who considered being Generation Z digital natives as they use technological devices along with google, iPod, email and chat rooms (Sweller, Kirschner \& Clark, 2007).

According to Creswell (2009); Creswell and Plano Clark (2017) followed by the cross- 
sectional survey, the distribution of the questionnaire was conducted and yielded 315 responses from the targeted 357 potential respondents which constitute an 88 $\%$ response rate. According to Krejcie and Morgan (1970), the minimum sample size for a population of 5196 is about 357 respondents' sample and also according to Roth \& BeVier (1994) the minimum acceptable level of response rate is $80 \%$. Thereby, the sample obtained within this study was an adequate representation of the total population. Questionnaires were an efficient data collection mechanism when the researcher knew exactly what is required and how to measure the variables of interest. Questionnaires can be administered personal, mailed to the respondents or electronically distributed (Sekaran, 2006). This study is made use of a closed-ended questionnaire to collect data from selected university undergraduates who are following the management stream.

The resulting data obtained from the respondents were entered into SPSS software version 21 and results were further entered into the Sobel test calculator in order to check the mediate relationship.

\section{Findings and Discussion}

\section{Respondent profile}

The respondent profile of the respondents formed the preliminary analysis. This is shown in Table I (Appendix B).

Accordingly, female undergraduates were the dominant category in the sample. In terms of the age categories, undergraduates were born in 1995 and 1996. Contemporary students in this age category are considered digital natives and effect multitaskers. In terms of university representations, the majority were from the University of Jayawardanapura as far as the sample represents a large proportion of undergraduates from the University of Jayawardhanapura.
Out of 315 surveyed students, all of them had at least one device. According to the survey results, the most commonly used technology device by the students was the smartphone. Among the surveyed student's laptop computers were slightly prevalent. 257 students had their laptops, and 110 had their desktops. Whereas, only less number of students used tab. $t$ and iPod which was 34 and 10 respectively. Further, statistics showed that six students had all of these five technology devices for their usage while only $54(17 \%)$ students had only one device.

\section{Internal consistency measures for the measurement model}

In determining the internal consistency of constructs in the model, Cronbach's alpha and KMO and Bartlett's test were used in line with recommendations from Hair et al. (2017) and Kline (2015). Table 2 (Appendix C) shows the results on the internal consistency measures of the reflective model.

The values obtained from Cronbach's for the reflective model show that the model achieved reliability standards as the value of Cronbach's Alpha greater than 0.7 is considered reliable (Nunnally, 1978). According to the factor analysis results (Appendix C), values for the KMO test were above 0.5 and all the values for Bartlett's test indicated below 0.05 which is confirmed the validity requirements of the data set. The KMO test was used to verify the sampling adequacy for the analysis.

Prior to the data analysis, missing values, linearity, multicollinearity, normality and outliers were tested and it was confirmed that all the assumptions were met and the data is normally distributed.

Objective 01: Determine the impact of SA on AP of university undergraduates.

To examine the impact of SA on AP multiple regression is carried out. As per Table 3 
(Appendix D), SA is statistically significant to AP.

The regression analysis revealed that the standardized coefficient values of SA is negatively impacted on AP. Therefore, $\mathrm{H} 1$ is supported. That emphasized that when the SA increases it will affect to decrease the AP of university undergraduates. R2, coefficient of determination which indicates $45.1 \%$ of the variance in AP can be predicted from the SA.

Objective 02: Determine the impact of $S A$ on TDMT.

The researcher used regression analysis to predict the TDMT based on IVs of SA. SA has a statistically significant relationship with the mediator variable $(\mathrm{F}=54.587$, sig $=0.000)$. It revealed that the standardized coefficient values of IV positively impact on the TDMT of university undergraduates. Thereby, analysis can be derived as university undergraduate's multitasking is high if their smartphones addiction is at a high level. Thereby, $\mathrm{H} 2$ is supported (Appendix E).

\section{Objective 03: Determine TDMT on AP of university undergraduate.}

The researcher used simple regression to predict the direct effects of TDMT on AP. Thereby, TDMT is statistically significant with AP $(\mathrm{p}<0.00)$. The regression analysis revealed that the standardized coefficient values of TDMT negatively impacted on AP of university undergraduates. Thereby, analysis can be derived as

university undergraduate's AP is high if their TDMT level is at a low level $(B=-$ $0.362 \mathrm{p}=0.00$ ). Therefore, H3 is supported by the results of the present study (Appendix F).

Objective 04: Determine the mediating effect of TDMT.

The Sobel test (Sobel 1982) is conducted to determine the significance of the indirect effects for mediator TDMT. The interactive calculator is employed (Preacher \& Leonardelli 2010). Accordingly, a significant indirect effect was found in the SA - TDMT- AP relationship (test statistics $=-1.20660863 ; \mathrm{p}<0.05)$. Thus, $\mathrm{H} 4$ is supported (Appendix G).

Further, the sizes of the products of the indirect effects for TDMT as a mediator are analyzed (Appendix H).

This study looked into SA of management undergraduates among four leading state universities in Sri Lanka. The purpose of this study was to describe the impact of SA on AP with the mediating effect of TDMT.

\section{Conclusion}

It can be concluded that higher SA leads to a better level of multitasking abilities among students. However, when it considers the field of academics, data analysis is confirmed that there is a significant negative impact of SA and TDMT on the AP. When undergraduates are highly addicted to smartphones, they spend less time on academic activities. Hence, the AP or GPA will be decreased. And also, TDMT mediates the relationship between IV and DV. When SA directly impacts on AP of the students, it also has an indirect impact through multitasking as well. Hence, it can be concluded that AP can be strengthened and enhanced by effectively utilizing the level of TDMT of the university undergraduates.

Ultimately these findings are also theoretically a line with the literature in threaded cognitive theory which showed attempting to pay attention to two stimuli simultaneously reduces one's ability to both pay attention and process either of those stimuli. Therefore, these findings give a clear-cut answer to the contrast findings on the relationship between SA and the AP. On the other hand, the generation $\mathrm{Z}$ digital natives cannot separate from disruptive technologies. Findings have proven that they 
are greater multitaskers and are considered to be superficial with the latest technologies. Thereby, with the emerging trends of smart classroom concepts in the education environment, multitasking with technologies should be effectively regulated for better AP.

Based on the findings, it is recommended that the students should reduce the use of smartphones and addiction to them and priorities their academic tasks (Hiscock, 2004; Selwyn, 2003). Many education institutions have restricted the use of smartphones and other technology in the classroom and while studying and some institutions have banned cell phones or else required students to keep them in a separate box by the door to be retrieved at the end of class. The concepts like "technology breaks" can be introduced to remove both internal and external distractions whenever they engage in learning.

\section{Suggestions for further studies}

The primary limitation of this study is the majority of the sample were born after 1995 and this will limit the generalizability of the finding to other age categories. Future research can incorporate a more diverse population. And also, this study is crosssectional. Thereby, longitudinal studies can be done in order to determine the variance level of academic performance. This study is also limited to the undergraduates in management faculties in Sri Lanka. Further research will replicate this study with a more diverse sample in terms of different streams. The study only relies on quantitative data, which confined the understanding of the phenomenon in more detail. For future studies, it will be better to use a mixed method and include students for indebting interviews or case studies. Further, future research can be conducted by actual measurements of actual time spent on multitasking behavior, through observation or online tracking methods. Further, it is recommended, to incorporate different methodologies to analyze the SA with different aspects in various contexts will facilitate to have a strong awareness of the effective utilization of technology devices.

\section{References}

Al-Barashdi, H. S., Bouazza, A., \& Jabur, N. H. (2015). Smartphone addiction among university undergraduates: a literature review. Journal of Scientific Research and Reports, 210-225. https://doi.org/10.9734/JSRR/2015/12245

Alfawareh, H. M., \& Jusoh, S. (2014). Smartphones usage among university students: Najran University case. International Journal of Academic Research, 6(2). https://doi.org/10.7813/2075-4124.2014/6-2/B.48

Aljomaa, S. S., Mohammad, M. F., Albursan, I. S., Bakhiet, S. F., \& Abduljabbar, A. S. (2016). Smartphone addiction among university students in the light of some variables. Computers in Human Behavior, 61, 155-164.

https://doi.org/10.1016/j.chb.2016.03.041

Alosaimi, F. D., Alyahya, H., Alshahwan, H., Al Mahyijari, N., \& Shaik, S. A. (2016). Smartphone addiction among university students in Riyadh, Saudi Arabia. Saudi Medical Journal, 37(6), 675-683.

https://doi.org/10.15537/Smj.2016.6.14430 
Praveeni S.M.N., Wickramasinghe C.N., KJM, 2021, 10 (Special Issue)

Bianchi, A., \& Phillips, J. G. (2005). Psychological predictors of problem mobile phone use. CyberPsychology \& Behavior, 8(1), 39-51. https://doi.org/10.1089/cpb.2005.8.39

Bijker, W. E., Hughes, T. P., \& Pinch, T. J. (Eds.). (1987). The social construction of technological systems: New directions in the sociology and history of technology. MIT press.

Calderwood, C., Ackerman, P. L., \& Conklin, E. M. (2014). What else do college students "do" while studying? An investigation of multitasking. Computers \& Education, 75, 19-29. https://doi.org/10.1016/j.compedu.2014.02.004

Creswell, J. W. (2009). Research Design Qualitative, Quantitative, and Mixed Methods Approaches ( $3^{\text {rd }}$ ed.). Thousand Oaks, Sage Publications.

Creswell, J. W., \& Clark, V. L. P. (2017). Designing and conducting mixed methods research. Sage publications.

Deloitte Global Mobile Consumer Survey: US Edition. A New Era in Mobile Continues; Touche Tohmatsu Limited: London, UK, 2018; pp. 2-16. Available online: https://www2.deloitte.com/content/dam/Deloitte/us/Documents/technology-mediatelecommunications/us-tmt-global-mobile-consumer-survey-exec-summary-2018.pd

Emanuel, R., Bell, R., Cotton, C., Craig, J., Drummond, D., Gibson, S., ... \& Lewis, J. (2015). The truth about smartphone addiction. College Student Journal, 49(2), 291-299.

Erdem, H., Kalkin, G., Turen, U., \& Deniz, M. (2016). The Effects of No Mobile Phone Phobia (Nomofobi) on Academic Performance among Undergraduate Students [Üniversite Öğrencilerinde Mobil Telefon Yoksunluğu Korkusunun (nomofobi) Akademik Başarıya Etkisi]. Süleyman Demirel University. The Journal of Faculty of Economics and Administrative Sciences, 21(3), 923-936.

Fox, A. B., Rosen, J. R., \& Crawford, M. (2009). Distractions, distractions: Does instant messaging affect college students' performance on a concurrent reading comprehension task? CyberPsychology \& Behavior, 12, 51-53.

https://doi.org/10.1089/cpb.2008.0107

Hair Jr, J. F., Hult, G. T. M., Ringle, C., \& Sarstedt, M. (2017). A primer on partial least squares structural equation modeling (PLS-SEM). Sage publications.

Hiscock, D. (2004). Cell phones in class: This, too, shall pass. Community College Week, 16(16), 4-5.

Hossain, M. E., \& Ahmed, S. Z. (2016). Academic use of smartphones by university students: A developing country perspective. The Electronic Library, 34(4), 651-665. https://doi.org/10.1108/EL-07-2015-0112

James, D., \& Drennan, J. (2005, December). Exploring addictive consumption of mobile phone technology. In Australian and New Zealand Marketing Academy conference, Perth, Australia. 
Praveeni S.M.N., Wickramasinghe C.N., KJM, 2021, 10 (Special Issue)

Kamran, S. (2010). Mobile phone: calling and texting patterns of college students in Pakistan. International Journal of Business and Management, (Ling), 26-36. https://doi.org/10.5539/IJBM.V5N4P26

Kibona, L., \& Mgaya, G. (2015). Smartphones' effects on academic performance of higher learning students. Journal of Multidisciplinary Engineering Science and Technology, 2(4), 777-784.

Kline, R. B. (2015). Principles and practice of structural equation modeling methodology in the social sciences, (4th ed.,). Guilford publications.

Krejcie, R. V., \& Morgan, D. W. (1970). Determining sample size for research activities. Educational and psychological measurement, 30(3), 607-610.

Lićwinko, J., Krajewska-Kułak, E., \& Łukaszuk, C. (2011). Internet addiction among academic youth in Białystok. World, 7, 11 .

https://doi.org/10.1097/NCN.0b013e318224b34f

Levine, L. E., Waite, B. M., \& Bowman, L. L. (2012). Mobile media use, multitasking and distractibility. International Journal of Cyber Behavior, Psychology and Learning (IJCBPL), 2(3), 15-29.

https://doi.org/10.4018/ijcbpl.2012070102

Preacher, K. J., \& Leonardelli, G. J. (2001). Calculation for the Sobel test. Retrieved January, 20, 2009.

Prensky, M. (2001). Digital natives, digital immigrants. On the horizon, 9(5).

Roberts, J., Yaya, L., \& Manolis, C. (2014). The invisible addiction: Cell-phone activities and addiction among male and female college students. Journal of behavioral addictions, 3(4), 254-265.

https://doi.org/10.1556/JBA.3.2014.015

Roth, P. L., \& BeVier, C. A. (1998). Response rates in HRM/OB survey research: Norms and correlates, 1990-1994. Journal of Management, 24(1), 97-117.

Salvucci, D. D., \& Taatgen, N. A. (2008). Threaded cognition: An integrated theory of concurrent multitasking. Psychological review, 115(1), 101.

Selwyn, N. (2003). Schooling the mobile generation: The future for schools in the mobilenetworked society. British journal of sociology of education, 24(2), 131-144. https://doi.org/10.1080/01425690301905

Shambare, R., Rugimbana, R., \& Zhowa, T. (2012). Are mobile phones the 21 st century addiction? African Journal of Business Management, 6(2), 573-577.

https://doi.org/10.5897/AJBM11.1940

Shaw, M., \& Black, D. W. (2008). Internet addiction. CNS drugs, 22(5), 353-365.

Kelaniya Journal of Management | 2021 | Vol. 10 | Special Issue | Page 33 
Praveeni S.M.N., Wickramasinghe C.N., KJM, 2021, 10 (Special Issue)

https://doi.org/10.2165/00023210-200822050-00001

Sobel, M. E. (1982). Asymptotic confidence intervals for indirect effects in structural equation models. Sociological methodology, 13, 290-312.

Sweller, J., Kirschner, P. A., \& Clark, R. E. (2007). Why minimally guided teaching techniques do not work: A reply to commentaries. Educational psychologist, 42(2), 115-121. https://doi.org/10.1080/00461520701263426

\section{Appendices}

\section{Appendix A}

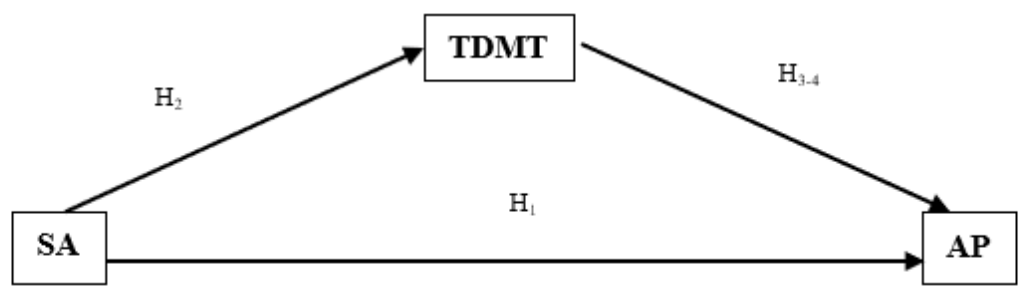

Figure 1: Model of the study

\section{Appendix B}

Table 1: Respondent profile

\begin{tabular}{lcc}
\hline Profile & Frequency & Percentage \\
\hline Gender & 91 & 29 \\
Male & 224 & 71 \\
Female & & \\
University name & 96 & 30 \\
University of Jayawardhanapura & 70 & 23 \\
University of Colombo & 63 & 20 \\
University of Kelaniya & 86 & 27 \\
Wayamba university of Sri Lanka & & \\
Type of devices & 315 & 100 \\
Smartphone & 110 & 35 \\
Desktop & 257 & 82 \\
Laptop & 10 & 3 \\
iPad & 34 & 11 \\
Tablet & & \\
\hline
\end{tabular}

Source: Survey results (2019) 
Praveeni S.M.N., Wickramasinghe C.N., KJM, 2021, 10 (Special Issue)

\section{Appendix C}

Table 2: Construct Validity and Reliability

\begin{tabular}{llcc}
\hline Constructs & Cronbach Alpha & KMO value & Bartlett's Test \\
\hline SA & 0.881 & 0.848 & .000 \\
TDMT & 0.846 & 0.834 & .000 \\
AP & 0.900 & 0.827 & .000 \\
\hline
\end{tabular}

Source: Survey results (2019)

\section{Appendix D}

Table 3: Regression Analysis of IV on DV

\begin{tabular}{|c|c|c|c|c|c|}
\hline \multirow{2}{*}{\multicolumn{2}{|c|}{ Model }} & \multicolumn{2}{|c|}{ Standardized Coefficients } & \multirow[b]{2}{*}{$\mathbf{t}$} & \multirow[b]{2}{*}{ Sig. } \\
\hline & & $\mathbf{B}$ & Std. Error & & \\
\hline 1 & (Constant) & 5.879 & .177 & 33.233 & .000 \\
\hline & SA & -0.260 & .053 & -5.353 & .000 \\
\hline & $\mathrm{R}^{2}$ & 0.451 & & & \\
\hline & $\mathrm{F}$ & 65.550 & & & .000 \\
\hline
\end{tabular}

a. Dependent Variable: AP

Source: Survey results (2019)

\section{Appendix E}

Table 4: Regression analysis of IV on Mediate variable

\begin{tabular}{|c|c|c|c|c|c|}
\hline & & \multicolumn{2}{|c|}{ Standardized Coefficients } & \multirow[b]{2}{*}{$\mathbf{t}$} & \multirow[b]{2}{*}{ Sig. } \\
\hline & & B & Std. Error & & \\
\hline \multirow[t]{2}{*}{1} & (Constant) & 5.879 & .177 & 33.233 & .000 \\
\hline & SA & 0.171 & .063 & 3.386 & .001 \\
\hline $\mathrm{R}^{2}$ & & 0.413 & & & \\
\hline F & & 54.587 & & & .000 \\
\hline
\end{tabular}

Source: Survey results (2019)

\section{Appendix F}

Table 5: Regression analysis of Mediate variable on DV

\begin{tabular}{|c|c|c|c|c|c|}
\hline \multirow{2}{*}{\multicolumn{2}{|c|}{ Model }} & \multicolumn{2}{|c|}{ Standardized Coefficients } & \multirow[b]{2}{*}{$\mathbf{t}$} & \multirow[b]{2}{*}{ Sig. } \\
\hline & & B & Std. Error & & \\
\hline \multirow[t]{3}{*}{1} & (Constant) & 4.454 & .151 & 29.502 & .000 \\
\hline & TDMT & -0.362 & .046 & -6.871 & .000 \\
\hline & $\mathrm{R}^{2}$ & 0.131 & & & \\
\hline & $\mathrm{F}$ & 47.207 & & & .000 \\
\hline
\end{tabular}

Source: Survey results (2019) 
Praveeni S.M.N., Wickramasinghe C.N., KJM, 2021, 10 (Special Issue)

\section{Appendix G}

Table 6: Soble Test

\begin{tabular}{lccc}
\hline & \multicolumn{3}{c}{ Sobel test statistics } \\
\cline { 2 - 4 } & Test statistic: & Std. Error: & $\boldsymbol{p}$-value: \\
\hline SA & -1.20660863 & 0.01094473 & 0.00394005 \\
\hline
\end{tabular}

Source: Survey results (2019)

\section{Appendix H}

Table 7: Size of the indirect effects with TDMT as a mediator

\begin{tabular}{|c|c|c|c|}
\hline Mediation Effect & Path a & Path b & Size: $a * b$ \\
\hline $\mathrm{SA} \longrightarrow \mathrm{TDMT} \longrightarrow \mathrm{AP}$ & 0.171 & -0.362 & -0.061902 \\
\hline
\end{tabular}

Source: Survey results (2019) 